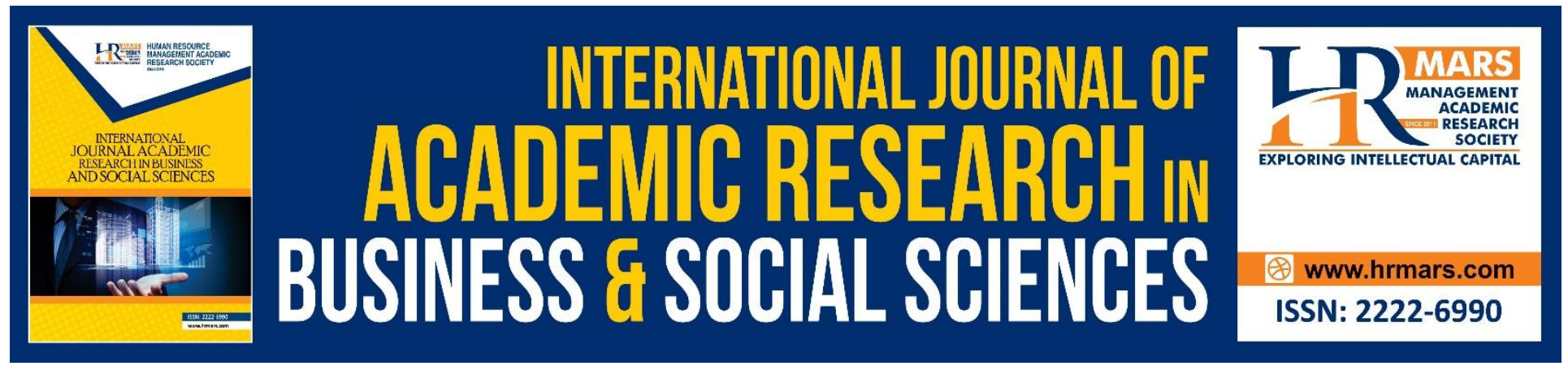

\title{
Human Resources Management and Employees' Practices at the Workplace: Enhancing Organizational Citizenship Behavior for Environment
}

Siti Sara Salleh, Mohd Fazly Mohd Razali, Ima llyani Ibrahim, Rozihana Shekh Zain, Zulkafli Mansor

To Link this Article: http://dx.doi.org/10.6007/IJARBSS/v10-i8/7540

DOI:10.6007/IJARBSS/v10-i8/7540

Received: 20 May 2020, Revised: 24 June 2020, Accepted: 21 July 2020

Published Online: 27 August 2020

In-Text Citation: (Salleh, Razali, Ibrahim, Zain, \& Mansor, 2020)

To Cite this Article: Salleh, S. S., Razali, M. F. M., Ibrahim, I I., Zain, R. S., \& Mansor, Z. (2020). Human Resources Management and Employees' Practices at The Workplace: Enhancing Organizational Citizenship Behavior for Environment. International Journal of Academic Research in Business and Social Sciences. 10(8), 305-317.

Copyright: (c) 2020 The Author(s)

Published by Human Resource Management Academic Research Society (www.hrmars.com)

This article is published under the Creative Commons Attribution (CC BY 4.0) license. Anyone may reproduce, distribute, translate and create derivative works of this article (for both commercial and non-commercial purposes), subject to full attribution to the original publication and authors. The full terms of this license may be seen

at: http://creativecommons.org/licences/by/4.0/legalcode

Vol. 10, No. 8, 2020, Pg. 305 - 317

http://hrmars.com/index.php/pages/detail/IJARBSS

JOURNAL HOMEPAGE

Full Terms \& Conditions of access and use can be found at http://hrmars.com/index.php/pages/detail/publication-ethics 


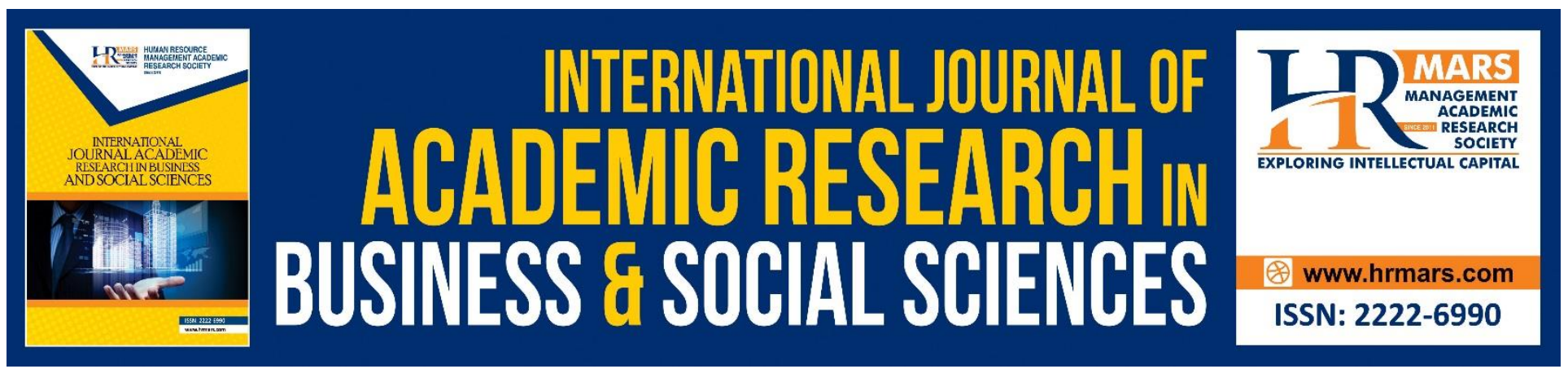

\title{
Human Resources Management and Employees' Practices at The Workplace: Enhancing Organizational Citizenship Behavior for Environment
}

\author{
Siti Sara Salleh \\ Student, Faculty of Business and Management, Universiti Teknologi MARA, Perlis Branch, \\ Arau Campus, 02600 Arau, Perlis, Malaysia \\ Email: sarasalleh26@gmail.com
}

\section{Mohd Fazly Mohd Razali, Ima Ilyani Ibrahim, Rozihana Shekh Zain, Zulkafli Mansor}

Senior Lecturer, Faculty of Business and Management, Universiti Teknologi MARA, Perlis Branch, Arau Campus, 02600 Arau, Perlis, Malaysia

Email:mohdfazly@uitm.edu.my, ilyani686@uitm.edu.my,rozihana@uitm.edu.my, zulkafli.mansor@uitm.edu.my

\begin{abstract}
High performance organization creates a conducive working environment that attempts to keep the employees happy and productive. It is one of the important things that need to be considered by any organization. Previously, there are so many studies regarding antecedents of Human Resources Management (HRM) practices towards Organizational Citizenship Behavior (OCB), but lack of Organizational Citizenship Behavior for Environment (OCBE). Due to this circumstance, this study aims to identify the influences of Human Resources Management (HRM) practices towards Organizational Citizenship Behavior for Environment (OCBE) at workplace by responding to the global warming issues. The integration of Training and Development, Compensation and Benefits, and Performance Appraisal are used in predicting the effect towards OCBE in this study. A total of 130 set of questionnaires have been distributed among employees in Kuala Lumpur using convenience sampling technique. The finding confirm that organization practices should incorporate environmental-friendly work culture among their employees in order to encounter with the environmental issues.
\end{abstract}

Keywords: Organizational Citizenship Behavior for Environment (OCBE), Human Resources Management (HRM) Practices, Training and Development, Compensation and Benefits, Performance Appraisal. 
INTERNATIONAL JOURNAL OF ACADEMIC RESEARCH IN BUSINESS AND SOCIAL SCIENCES Vol. 10, No. 8, 2020, E-ISSN: 2222-6990 @ 2020 HRMARS

\section{Introduction}

Clean environment is needed in every country and city in this world to ensure that people are comfortable to continue their daily activities especially in working area. A growing number of employees complaining about experiencing utmost hot weather when working outside of the building and while doing field work. This situation happened by virtue of global warming phenomenon.

Malaysia is one of the countries that get affected by global warming. Moreover, the $1.5^{\circ} \mathrm{C}$ Global Warming Special Report released by the Intergovernmental Panel on Climate Change (IPCC) on 8 October 2018 identified South East Asia as one of the regions that would be hardest hit in the near future by climate change (Varkkey, 2019). Temperature records have shown warming trends in most places including Malaysia in the past 30-50 years. Climate change in Malaysia has shown the negative impact of the phenomenon on human habitats such as agriculture, forests, water resources, coastal resources, health and energy sector (Haliza, 2018).

In vogue, environmental change is regarded as one of the biggest challenges to society. The ecological crisis is undeniable, systemic and persistent, impacting every aspect of our lives and the future. Thus, Malaysia government need to be proactive in responding to the environmental crisis and challenges in determining the best way to reciprocate and illuminate the problems.

The public concern about the problems of climate change led to the emergence of new environmental regulations. In Malaysia, a new Ministry of Natural Resources and Environment (MNRE) has been established. The MNRE has largely perpetuated the conventional focus on development and the production of wealth with all the purposes of a separate and empowered ministry with environmental issue. The ministers continue to argue that land and forests are national assets that can't be left dormant. As a result, Malaysia's economy continues to witness tremendous growth and development, driven by the abundance of natural resources and raw materials. Besides that, Malaysia government take initiatives to primary school students explored the feasibility of a Climate Change Act. Malaysian student interested in participating to innovated to help mitigate the effects of climate change. Comparatively, the solutions provided by the students range from air pollution detecting drones, forest fire warning system to beeping bins capable of differentiating waste types, recycling waste, biodegradable plastic compounds, solar-powered traffic lights, carbon dioxide converters and a variety of filters, detectors, sensors and automated systems that harness energy from natural sources (The Star, 2019). This action manifest that everyone actually cares about our environment and making an effort to decode the predicament state.

In consonance with Wagner \& Omran (2011), Malaysia is also taking steps to adopt the Green Building Strategy as an efficient way to minimize energy use, greenhouse gas emissions, sick building syndrome and the overall effects of construction patterns on the environment. Multiple events and platforms were created in Malaysia in order to increase the level of awareness regarding this matter. As an example, The International Greentech and Eco Products Exhibition and Conference Malaysia (IGEM) 2019 marks its $10^{\text {th }}$ anniversary as the largest trade event for green technologies and ecosolutions in South East Asia. This kind of events will hopefully increase the awareness in the country especially to those who work in the industries. The company in Malaysia need to focus more on environmental management and employee awareness toward the environmental issues. Hence, the objective of this study was to identify the predictors that influence the HRM practices towards OCBE among Malaysian since it is very challenging to create OCBE with HRM practices in all organization in Malaysia without appropriate information and instruction. 
INTERNATIONAL JOURNAL OF ACADEMIC RESEARCH IN BUSINESS AND SOCIAL SCIENCES Vol. 10, No. 8, 2020, E-ISSN: 2222-6990 @ 2020 HRMARS

\section{Literature Review}

This literature review study the intended effects that linked the existing knowledge gaps by investigate the relationship between Training and Development, Compensation and Benefits, Performance Appraisal and Organizational Citizenship Behaviour for Environment.

\section{Organizational Citizenship Behaviour for Environment (OCBE)}

Organizational Citizenship Behaviour (OCB) has been defined as personal and voluntary behavior that is not directly mentioned in an organization's official reward system. Though, it does contribute to the organization's effectiveness and efficiency (Appelbaum et al., 2004). Behaviour in this category consist of the employees may engage in at their discretion, and that facilitated the effectiveness of the organization, and promote the interests for the environment (Brief \& Motowidlo, 1986). Earlier researchers in organizational relationship behavior (OCB) were mostly conducted to identify employees' responsibility or behaviors in organization that were often overlooked; but Daily, Bishop \& Govindarajulu (2009) concocted new type of Organizational Citizenship Behavior toward environment or can be call as "pro-environment behavior" and define as the employees' effort toward environment that related discretionary perform in an organization which not rewarded or required from organization. Hence, OCBE is related to, but still dissimilar from OCB because OCBE can be define as employees' voluntary act which the organization cannot pay or obtain directions to the improvement of the environment (Daily, Bishop \& Govindarajulu, 2009). Employee's contribution and involvement in green programs in the organization would gain multiple benefits for the organization.

Boiral \& Paille (2012) measured the OCBE based on eco-initiatives, eco-civic engagement, and eco-helping. Eco-initiative was interrelated with pro-environmental initiatives driven by an employee which include activities of the environment in the organization. This will skyrocket the environmental performance of organization eco-civic engagement and could contributes to environmental initiatives in an organization, such as joining a program or event related to environment awareness that organized by the company. It is compulsory to support environmental events in order to achieve environmental objectives. As a result, the benefit of developing an inclusive environmental policy led to foster perspective of ecological issues or establishing an environmental committee of voluntary employees by getting support from the organization. According to Testa et al. (2016), eco-helping is voluntary assistance to workers in addressing environmental concerns; promotion of team cooperation to address complex environmental issues, exchanging environmental knowledge with recruits and helping colleagues participating in a pollution reduction programme. Thus, it could alleviate the organization in getting sterling result of environmental performance.

Organizational Citizenship Behaviour for Environment (OCBE) is employee judgmental behaviours whereby employee will express their willingness to collaborate with their organization and co-worker by performing behaviours in the company that give benefits to natural environment (Boiral \& Paille, 2012). Subsequently, the employee might develop, suggest, and share new practices in the organization.

As stated by Delaney \& Huselid (1996), there is connection between key HRM and OCBE. In order to develop of organizational citizenship behavior for environment perspective in the organization, HRM practices ought to end up more inventive and in term with environmental objectives. It is important for human resources professional to watch, understand and embrace the objectives of environmental conduct or OCBE to give information about the environmental execution. 
INTERNATIONAL JOURNAL OF ACADEMIC RESEARCH IN BUSINESS AND SOCIAL SCIENCES Vol. 10, No. 8, 2020, E-ISSN: 2222-6990 ๑ 2020 HRMARS

Human resources professional can shape and influence the employee's practices and also became the ones that can help to changing the working environment to be more environmental-friendly.

\section{Training and Development}

Training is one of the attempts of the employer to share the expertise and skills with its workers to excel in the increasingly self-driven competitive performance contexts of the new workplace. It is becoming popular for organizations to assign responsibility for key educational decisions to their employees. Training is a crucial element in developing intellectual capital. It dealt with enhancing different skills to a desired level through preparation and practice. Carbery \& Cross (2015) and Noe (2010) stated that training is a plan and effort system to improve knowledge, skill, and abilities of an employees throughout the learning process which is crucial requirement to perform effectively in the organization. It is a learning process in order to transfer the information, knowledge, and skill from the person who knows to the employee who does not know or cannot do. Besides that, Carbery \& Cross (2015) initiated that development is the activity or ongoing acquisition of skill and knowledge that lead to a long-term career growth of employee for future job responsibilities.

As reported by Yazdanifard (2014), training and development is a developmental structure of the knowledge, skills and abilities that the employees need to achieve goal of a task effectively. It is because to improve the organization's activities where it desires to get better performance and positive results. Nevertheless, some studies often called training and development as Human Resources Development (HRD) because this area is improving human to remain competitive and can fit well in the market. In order to improve employee's productive and satisfaction, the employer need to understand that training could support employee because it can remain competitive by continually investing the knowledge in their workers (Aguinis \& Kraiger, 2009).

The key area for enhancing the OCBE is to have an appropriate means of training and development in order to increase the growth of employee engagement understanding relating to the efforts of an organization towards sustainability. In the opinion by Yazdanifard (2014), it can be seen that growing employee engagement through company investing in the training and development system will enhance environmental citizenship behavior (OCBE) and contribute to sustainable organizational growth.

\section{Compensation and Benefits}

In accordance with Byars \& Rue (2006), compensation applies to any of the extrinsic benefits workers earn because of their committed in their works; such as wages, bonuses, and benefits. Meanwhile, Nankervis, Compton \& Baird (2008) explain that benefits can be tangible such as health benefits and paid leave, or in non-financial terms, such as flexible job conditions and wellness programs to improve employee productivity, happiness and dedication.

Compensation and benefits are the most crucial part of HRM activities. It is because compensation and benefit can help to reinforce the organizational culture and value, to drive organization until achieving its strategic business objective (Meija \& Welbourne, 1991). In conformity with Raymond (2014), rewarding desire result and compensation and benefits policies can enhance employee behaviour in the workplace and serve as a tool for motivating job performance and enhancing organizational effectiveness at the uppermost level. Organization need to be more innovative in ensuring more voluntary behaviour that could motivate employees to act as a voluntary 
INTERNATIONAL JOURNAL OF ACADEMIC RESEARCH IN BUSINESS AND SOCIAL SCIENCES Vol. 10, No. 8, 2020, E-ISSN: 2222-6990 @ 2020 HRMARS

worker. The rewarding employee for voluntary behaviour will be an essential part of human resources management implementation because it can reinforce empowerment and ethical decision making of the worker to continually motivating their pro-environmental behavior (OCBE) (Cruces, 2001).

\section{Performance Appraisal}

Performance appraisal is a comprehensive assessment of employee performance and a recognition of the ability of individual to improve and develop career path. Performance appraisal is also used to differentiate between workers, to recognise strength and weaknesses of workers, to analyse Human Resources (HR) processes, to record personnel decisions and to enhance employee performance (Cleveland et al., 2003). It is an overview of measurement in an organization to evaluate individual effectiveness and achievement. It also is an explanation of individual job related to strength and weaknesses to make a decision about the individual career enhancement. Moreover, performance appraisal can only achieve a strategic aim if assessments is consistent to the goals of the company and the performance input is indeed conveyed to the workers (Noe, Hollenback, Gerhart \& Wright, 2011).

Furthermore, employees will support the appraisal system that being introduced if they understand the performance evaluation process, agree on the meaning orientation of the system by having an agreement with management on the performance metrics used have trust in the accuracy of the performance measurement and believe that there is no ratter bias (De \& Pritchard, 2006). Management in the organization need to focuses to the important aspect of performance appraisal which is to meet the standards of reliability, validity, and impartiality and to ensure that the performance appraisal is effective. It can be delivered as a useful feedback to the employees' performance, so that they can make improvement in the organization. However, it is a bit challenges when it comes to apply performance appraisal for evaluating OCBE because organization need to create a performance management system to develop OCBE standard and enhance achievement of OCBE in organization (Steg \& Vlek, 2009).

\section{Research Framework and Hypotheses}

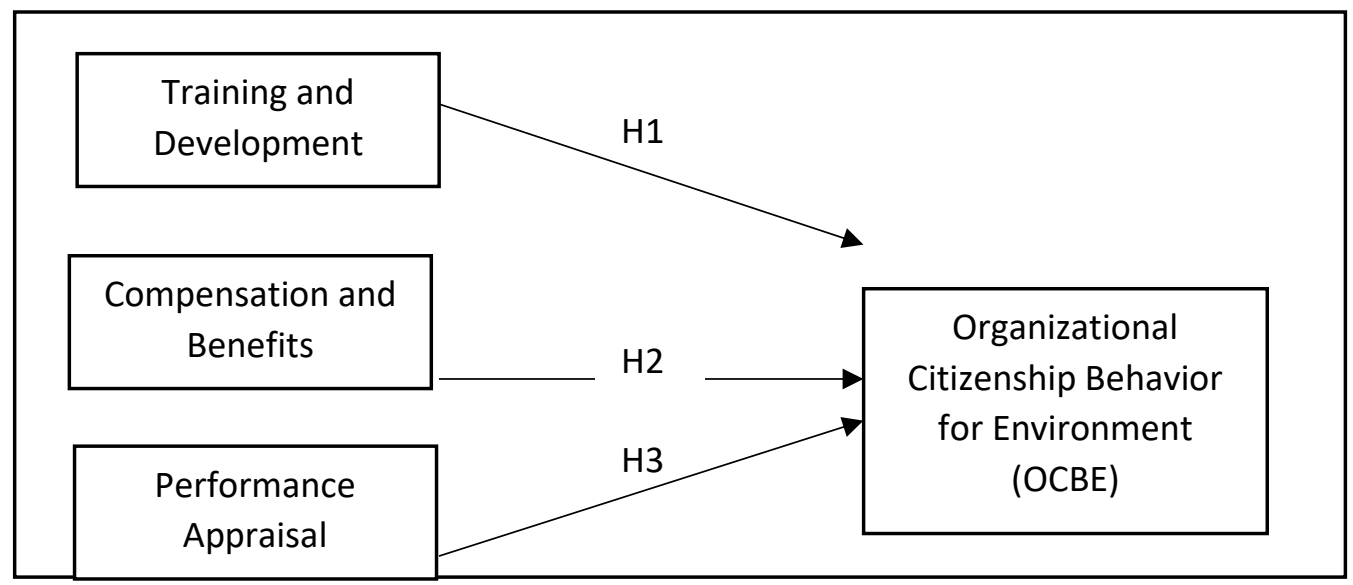

Figure 1 Theoretical Framework

(Sources: Boiral \& Paolle (2012); Demo et al., (2012) Amin et al., (2014) 
INTERNATIONAL JOURNAL OF ACADEMIC RESEARCH IN BUSINESS AND SOCIAL SCIENCES

Vol. 10, No. 8, 2020, E-ISSN: 2222-6990 @ 2020 HRMARS

$\mathrm{H1}$ : There is a significant relationship between training and development with organizational citizenship behaviour for environment (OCBE).

$\mathrm{H} 2$ : $\quad$ There is a significant relationship between compensation and benefits with organizational citizenship behaviour for environment (OCBE).

H3: There is a significant relationship between performance appraisal with organizational citizenship behaviour for environment (OCBE).

\section{Methodology}

The instrument used for this study were adapted from various sources. This questionnaire comprises of 33 questions including demographics.

Table 1 The Source for Questionnaires for Each Variables

\begin{tabular}{|l|l|c|}
\hline \multicolumn{1}{|c|}{ Variable } & \multicolumn{1}{|c|}{ Source } & No. of Item \\
\hline $\begin{array}{l}\text { Organizational Citizenship } \\
\text { Behaviour (OCBE) }\end{array}$ & Boiral and Paille (2012) & 10 \\
\hline Training and Development & Demo, Neiva, Nunes and Rozzett (2012) & 6 \\
\hline $\begin{array}{l}\text { Compensation and } \\
\text { Benefits }\end{array}$ & Demo, Neiva, Nunes and Rozzett (2012) & 5 \\
\hline Performance Appraisal & Amin, Ismail, Rasid and Selemani (2014) & 5 \\
\hline
\end{tabular}

In order to complete this research, the primary and secondary data was used as sources. The length of data collection period is about 9 weeks which is $18^{\text {th }}$ May 2020 until $24^{\text {th }}$ July 2020 . In this study, the questionnaires with five-point Likert Scale were used and distributed randomly to 130 employees that works in different industry around Kuala Lumpur. Due to COVID-19 pandemic, the questionnaires only obtainable through online. The researcher used convenience sampling technique to select the sample where several random offices were selected in this study. Unfortunately, only 102 was return successfully with complete response. Table 2 depict the alpha value and mean of each variable. The reliability of the questionnaires ranges from 0.697 to 0.869 which indicates that they were consistent and appropriate for the study (Nunnaly, 1978).

Table 2 The reliability result of the questionnaires

\begin{tabular}{|c|c|c|c|}
\hline $\begin{array}{c}\text { Organizational } \\
\begin{array}{c}\text { Citizenship Behaviour for } \\
\text { Environment }\end{array}\end{array}$ & $\begin{array}{c}\text { Training and } \\
\text { Development }\end{array}$ & $\begin{array}{c}\text { Compensation and } \\
\text { Benefits }\end{array}$ & $\begin{array}{c}\text { Performance } \\
\text { Appraisal }\end{array}$ \\
\hline$\alpha=0.869$ & $\begin{array}{c}\alpha=0.766 \\
(\mu=4.156)\end{array}$ & $\begin{array}{c}\alpha=0.776 \\
(\mu=4.082)\end{array}$ & $\alpha=0.697$ \\
$(\mu=4.144)$ & $(\mu=4.202)$ \\
\hline
\end{tabular}

\section{Finding and Discussion}

As mentioned earlier, this study was conducted within 9 weeks toward employees that work in various company located in Kuala Lumpur. Among those who participated, most of the respondents is female (58.8\%) within the range of $20-29$ years old $(47.1 \%)$. The details of the Frequency of Distribution Analysis are shown in Table 3. 
INTERNATIONAL JOURNAL OF ACADEMIC RESEARCH IN BUSINESS AND SOCIAL SCIENCES Vol. 10, No. 8, 2020, E-ISSN: 2222-6990 @ 2020 HRMARS

Table 3 Result of Distribution Analysis Frequency

\begin{tabular}{|c|c|c|c|}
\hline Variables & Categories & Frequency $(\mathrm{N})$ & Percentage (\%) \\
\hline \multirow[t]{2}{*}{ Gender } & Male & 42 & $41.2 \%$ \\
\hline & Female & 60 & $58.8 \%$ \\
\hline \multirow[t]{6}{*}{ Age } & Less than 20 years old & 7 & $6.9 \%$ \\
\hline & $20-29$ years old & 48 & $47.1 \%$ \\
\hline & 30-39 years old & 23 & $22.5 \%$ \\
\hline & $40-49$ years old & 14 & $13.7 \%$ \\
\hline & $50-59$ years old & 10 & $9.8 \%$ \\
\hline & 60 years old $\&$ above & - & - \\
\hline \multirow[t]{4}{*}{ Race } & Malay & 88 & $86.3 \%$ \\
\hline & Chinese & 10 & $9.8 \%$ \\
\hline & Indian & 1 & $1 \%$ \\
\hline & Others & 3 & $2.9 \%$ \\
\hline \multirow[t]{3}{*}{ Marital Status } & Single & 61 & $59.8 \%$ \\
\hline & Married & 35 & $34.3 \%$ \\
\hline & Single Parent & 6 & $5.9 \%$ \\
\hline \multirow[t]{6}{*}{ Number of Children } & No children & 65 & $63.7 \%$ \\
\hline & 1-2 children & 21 & $20.6 \%$ \\
\hline & 3-4 children & 12 & $11.8 \%$ \\
\hline & 5-6 children & 3 & $2.9 \%$ \\
\hline & 7-8 children & 1 & $1 \%$ \\
\hline & Above 8 & - & - \\
\hline \multirow[t]{7}{*}{ Level of Education } & SPM & 4 & $3.9 \%$ \\
\hline & Certificate & 1 & $1 \%$ \\
\hline & STPM & 11 & $10.8 \%$ \\
\hline & Diploma & 43 & $42.2 \%$ \\
\hline & Degree & 36 & $35.3 \%$ \\
\hline & Master & 7 & $6.9 \%$ \\
\hline & PhD & - & - \\
\hline \multirow[t]{6}{*}{ Working experience } & $1-5$ years & 51 & $50 \%$ \\
\hline & $6-10$ years & 24 & $23.5 \%$ \\
\hline & $11-15$ years & 10 & $9.8 \%$ \\
\hline & $16-20$ years & 4 & $3.9 \%$ \\
\hline & $21-25$ years & 6 & $5.9 \%$ \\
\hline & 26 years and above & 7 & $6.9 \%$ \\
\hline
\end{tabular}

In order to achieve the researchers' objectives in investigating the relationship between Training and Development, Compensation and Benefits, Performance Appraisal with Organizational Citizenship Behaviour for Environment (OCBE), the data were analysed using Pearson Correlation Analysis. The results in Table 4 showed that there is a significant relationship between each of the independent variables with the dependent variable. However, the strength of the relationship is 
INTERNATIONAL JOURNAL OF ACADEMIC RESEARCH IN BUSINESS AND SOCIAL SCIENCES Vol. 10, No. 8, 2020, E-ISSN: 2222-6990 @ 2020 HRMARS

differed. The most correlated with OCBE is Training and Development ( $r=.733, p=.000)$; followed by Compensation and Benefits $(r=.645, p=.000)$ and Performance Appraisal $(r=.607, p=.000)$.

Table 4 Pearson Correlation Between the Variables

\begin{tabular}{llll}
\hline & $\begin{array}{l}\text { Training and } \\
\text { Development }\end{array}$ & $\begin{array}{l}\text { Compensation } \\
\text { and Benefits }\end{array}$ & $\begin{array}{l}\text { Performance } \\
\text { Appraisal }\end{array}$ \\
\hline $\begin{array}{l}\text { Organizational Citizenship } \\
\text { Behaviour for Environment (OCBE) }\end{array}$ & 0.733 & 0.645 & 0.607 \\
\hline
\end{tabular}

**Correlation is significant at the 0.01 level (2-tailed)

Next, Multiple Regression test was conducted in order to understand the predicted power of the factors that affect Organizational Citizenship Behaviour for Environment (OCBE) among employees in Kuala Lumpur. The result shows the adjusted $r^{2}$ is 0.615 , with a different weightage of the standardized coefficient. Among all, there are two independent variables which is Training and Development $(\beta=0.519,0.000)$ and Compensation and Benefits $(\beta=0.310, p=0.000)$ have a relationship with the DV. However, Performance Appraisal $(\beta=0.062, p=0.529)$ was not significant with OCBE.

Table 5 Multiple Regression Analysis

\begin{tabular}{lcc}
\hline \multicolumn{1}{c}{ Variable } & $\begin{array}{c}\text { Unstandardized and Coefficient } \\
\text { Beta }\end{array}$ & Sig \\
\hline Training and Development & .519 & .000 \\
Compensation and Benefits & .310 & .000 \\
Performance Appraisal & .062 & .529 \\
\hline F change & 54.740 & \\
R square & .626 & \\
Adjusted R square & .615 & \\
\hline
\end{tabular}

$* * p<.05$

\section{Discussion and Conclusion}

The outcome of this study shows that Training and Development has positive significant relationship with OCBE among employees in Kuala Lumpur, Malaysia. It is because in Malaysia, there a lot of events that supported green practices with the intention to create awareness toward environmental issues. Besides, this finding is also consistent with Zibarras and Coan (2015) result which show that the significant relationship between Organizational Citizenship Behaviour for Environment (OCBE) and training and development in UK since the critical area for improving environmental citizenship behaviour (OCBE) is to provide adequate preparation and development to ensure the workers are well informed about environmental protection and the environmental effect. This is how they can learn to respond to changes in the environment and will increase the awareness of an organization's sustainability efforts (Mandip, 2012; Zibarras \& Coan, 2015). In the direction of to increase the Organizational Citizenship Behaviour for Environment (OCBE), it can be done by focusing on training and development such as orientation programs and environmental management 
INTERNATIONAL JOURNAL OF ACADEMIC RESEARCH IN BUSINESS AND SOCIAL SCIENCES Vol. 10, No. 8, 2020, E-ISSN: 2222-6990 @ 2020 HRMARS

workshop (Razab, Udin \& Osman, 2015). If the training and development conducted effectively, multiple parties will gain benefits.

The second variable of this research was Compensation and Benefits, where the regression analysis result showed that there is significant relationship with OCBE. This result is consistent with Shen, Netto \& Tang (2010), it stated that compensation and benefit are entirely related to OCBE because it can motivate the employee to create environmental improvement in the organization (Renwick, Redman \& Maguire, 2008). In addition, Ahmad (2015) also believes that incentives and rewards will affect the overall amount of OCBE working towards environmental protection because bonuses and compensation can be viewed as possible mechanism for promoting environmental practices in organizations towards environmentally friendly measures among the employees.

Last but not least, the third variable is Performance Appraisal. The Regression Analysis of this variable shows that there is no significant relationship between Performance Appraisal and OCBE. This result is supported by Shen, Netto \& Tang (2010) that stipulated there is no significant relationship between performance appraisal and OCBE because it has been widely known to integrated performance appraisal to OCBE among employees.

\section{Recommendations}

In order to ensure the employees well informed and aware about the environmental issues, they should be involved in events that endeavour environmentally friendly programs. Hopefully by volunteering in events, employees can learn how to appreciate and make our environment to be better in the future. A suitable training and development program must be instilled in ensuring the employees can be creative in maintaining and sustaining the use of energy. Besides that, they also can practice what they learn at the training and become their working culture. An effort and direction should be commensurate to create green management in the work place. In addition, the employees will become more concerned about environmental management and effects since they can learn how to react to changes in the environment and raise awareness of an organization's efforts towards sustainability (Mandip, 2012; Zibarras \& Coan, 2015).

In boosting the motivation of the employees, organization should offer incentives for employees in order to enhance concern and practices towards green environment concept at the work place. By doing this, such encouragement about environmental issues awareness will practically help to save the environment even with their minimum actions from employees. According to Shen, Netto, \& Tang (2010), compensation and benefit is entirely related to OCBE because it can motivate the employee to create environmental improvement in the organizations. Moreover, Ahmad (2015) also agree that incentives and rewards can influence the maximum of Organizational Citizenship Behavior for Environment (OCBE) at workplace toward environmental management. Eventually, it will improve the employee's motivation on preserving the nature while performing high productivity in the organization.

Succinctly, this study scouted partially possible forms of OCBE. The questionnaire design was not all embracing and only cover partially possible discretionary behaviours for the environment. The literature in this study were not comprehensive in representing the spectrum and consensus of OCBE. On that account, numerous platform and avenues of research suggest that OCBEs are worthwhile for investigation and exploration. Nevertheless, the research that was conducted in this area, it clearly states that the importance of instilling and nurturing the green management concept and hopefully the result of this of this study could alleviate more profound research on this new themes and subject. 
INTERNATIONAL JOURNAL OF ACADEMIC RESEARCH IN BUSINESS AND SOCIAL SCIENCES Vol. 10, No. 8, 2020, E-ISSN: 2222-6990 @ 2020 HRMARS

\section{Conclusion}

This research aims to investigate the Organizational Citizenship Behaviour for Environment between Training and Development, Compensation and Benefits and Performance Appraisal. Based on the findings, Training and Development $(\mathrm{H} 1)$ and Compensation and Benefits $(\mathrm{H} 2)$ have positive relationship that influence the Organizational Citizenship Behaviour for Environment (OCBE). However, it is different for Performance Appraisal where the relationship is not significant. In consequence, organization which accessible more involvement of Human Resources practices to OCBE need to highlight on training and development program and also compensation and benefits for improvement of OCBE in the organization.

A future study and direction is to explore the additional effects of these green practices on OCBE. A holistic approach about the effect of macro level policy on employee OCBEs in the organization. Thus, to examine the impact individual employee's OCBE after the establishment of the policy. Among the national level policy, the study on introducing subject during school or even in university level should be essential. In fostering positive behaviors, it is admissible for schools and university from an education and will continue to the lifelong education in corporate perspective. This research will explored on the ways and method of employees perceive and practice OCBE at workplace. OCBE engagement will start from school to university level as become part of new developed culture.

\section{Contribution}

In implementing well developed policy on the green management, it will reduce waste and cost optimization that significantly reaching the environmental sustainability. In the long run, it will nurture the positive employee engagement. Moreover, having the cautious thought about preserving the natural environment will subsequently enhancing the ROI of the organization. The management in extraction and exploitation of raw materials to the generation of waste will no longer be neglected by the organization. Hopefully this concept could reduce the effect of global warming, earth quick or any natural disaster. Thus, activities on economic value will be balanced with the social and environmental value.

\section{Acknowledgement}

Thank you to all respondents for their participation and contribution especially during the collection of data since this study had been done during the pandemic of COVID-19.

\section{References}

Aguinis, H., \& Kraiger, K. (2009). Benefits of training and development for individuals and teams, organizations, and society. Annual review of psychology, 60, 451-474.

Ahmad, S. (2015). Green Human Resource Management: Policies and Practices. Cogent Business \& Management, 2(1), 1030817.

Amin, M., Ismail, W. K. W., Rasid, S. Z. A., \& Selemani, R. D. A. (2014). The impact of human resource management practices on performance. The TQM Journal.

Appelbaum, S., Bartolomucci, N., Beaumier, E., Boulanger, J., Corrigan, R., Dore, I., \& Serroni, C. (2004). Organizational citizenship behavior: a case study of culture, leadership and trust. Management decision. 
INTERNATIONAL JOURNAL OF ACADEMIC RESEARCH IN BUSINESS AND SOCIAL SCIENCES

Vol. 10, No. 8, 2020, E-ISSN: 2222-6990 @ 2020 HRMARS

Boiral, O., \& Paillé, P. (2012). Organizational citizenship behaviour for the environment: Measurement and validation. Journal of business ethics, 109(4), 431-445.

Brief, A. P., \& Motowidlo, S. J. (1986). Prosocial organizational behaviors. Academy of management Review, 11(4), 710-725.

Byars, L. L., \& Rue, L. W. (2006). Human Resource Management McGraw-Hill. International Edition.

Carbery, R., \& Cross, C. (Eds.). (2015). Human resource development: A concise introduction. Palgrave.

Cleveland, J. N., Mohammed, S., Skattebo, A. L., \& Sin, H. P. (2003). Multiple purposes of performance appraisal: A replication and extension in Annual conference for the Society for Industrial and Organisational Psychology (pp. 68-72).

Cruces, L. (2001). Achieving Sustainability Through Attention to Human Resource Factors in Environmental Management, 21(12), 1539-1552.

Daily, B. F., Bishop, J. W., \& Govindarajulu, N. (2009). A conceptual model for organizational citizenship behavior directed toward the environment. Business \& Society, 48(2), 243-256.

Delaney, J. T., \& Huselid, M. A. (1996). The impact of human resource management practices on perceptions of organizational performance. Academy of Management journal, 39(4), 949-969

Demo, G., Neiva, E. R., Nunes, I., \& Rozzett, K. (2012). Human resources management policies and practices scale (HRMPPS): Exploratory and confirmatory factor analysis. BAR-Brazilian Administration Review, 9(4), 395-420.

De Nisi, A. S., \& Pritchard, R. D. (2006). Performance appraisal, performance management and improving individual performance: A motivational framework. Management and Organization Review, 2(2), 253-277.

Gomez-Mejia, L. R., \& Welbourne, T. (1991). Compensation strategies in a global context. Human Resource Planning, 14(1), 29-41.

Haliza, A. R. (2018). CLIMATE CHANGE SCENARIOS IN MALAYSIA: ENGAgING THE PUBLIC. International Journal of Malay-Nusantara Studies, 1(2), 55-77.1(2), 55-77.

Mandip, G. (2012). Green HRM: People Management Commitment to Environmental Sustainability. Research Journal of Recent Science, 1, 244-253.

Nankervis, A., Compton, R., \& Baird, M. (2008). Evolution of Human Resource Management. Human Resource Management: Strategies \& Processes, 2-40.

Noe, R. A. (2010). Employee Training and Development. (Seventh, Ed) New York: McGraw Hill Education.

Raymond, N. A., Hollenback, J. R., Gerhart, B., \& Wright, P. M. (2011). Fundamental of Human Resources Management.

Nunnally, J. C. (1978). Psychometric theory (2 ${ }^{\text {nd }}$ ed.). New York: McGraw-Hill.

Raymond, S. (2014). Human Resource Management. Australia: Wliley.

Razab, M. F., Udin, Z. M., \& Osman, W. N. (2015). Understanding the role of GHRM towards environmental performance. Journal of Global Business and Social Entrepreneurship (GBSE), 1(2), 118-125.

Renwick, D., Redman, T., \& Maguire, S. (2008). Green HRM: A review, process model, and research agenda. University of Sheffield Management School Discussion Paper, 1, 1-46.

Shen, J., D'Netto, B., \& Tang, J. (2010). Effects of human resource diversity management on organizational citizen behaviour in the Chinese context. The International Journal of Human Resource Management, 21(12), 2156-2172. 
INTERNATIONAL JOURNAL OF ACADEMIC RESEARCH IN BUSINESS AND SOCIAL SCIENCES

Vol. 10, No. 8, 2020, E-ISSN: 2222-6990 @ 2020 HRMARS

Steg, L., \& Vlek, C. (2009). Encouraging pro-environmental behaviour: An integrative review and research agenda. Journal of environmental psychology, 29(3), 309-317.

Testa, F., Heras-Saizarbitoria, I., Daddi, T., Boiral, O., \& Iraldo, F. (2016). Public regulatory relief and the adoption of environmental management systems: a European survey. Journal of environmental planning and management, 59(12), 2231-2250.

The Star. (2019). Tackling the issue of climate change. Retrieved from https://www.thestar.com.my/news/education/2019/10/20/tackling-the-issue-of-climatechange

Varkkey, H. (2019). Winds of Change in Malaysia: The Government and the Climate. Retrieved from https://helenavarkkey.wordpress.com/2019/02/27/article-in-heinrich-boll-stiftung-windsof-change-in-malaysia-the-government-and-the-climate/

Wagner, K., \& Omran, A. (2011). The making of green buildings: viable pathways to curb global warming in Malaysia. Annals of the Faculty of Engineering Hunedoara, 9(2), 199

Yazdanifard, R. (2014). the Impact of Employee Training and Development on Employee. Research Gate, 2(6), 91-93. https://doi.org/10.6007//IJARBSS/v6-i1/1987

Zibarras, L. D., \& Coan, P. (2015). HRM practices used to promote pro-environmental behavior: a UK survey. The International Journal of Human Resource Management, 26(16), 2121-2142. 